\title{
Evaluation of selective dry cow treatment following on-farm culture: Risk of postcalving intramammary infection and clinical mastitis in the subsequent lactation
}

\author{
M. Cameron, ${ }^{* 1}$ S. L. McKenna, ${ }^{*}$ K. A. MacDonald, ${ }^{*}$ I. R. Dohoo, ${ }^{*}$ J. P. Roy,† and G. P. Keefe* \\ ${ }^{*}$ Department of Health Management, Atlantic Veterinary College, University of Prince Edward Island, Charlottetown, Prince Edward Island, \\ Canada C1A 4P3 \\ †Faculté de médecine vétérinaire, Université de Montréal, Saint-Hyacinthe, Québec, Canada J2S 7C6
}

\begin{abstract}
The objective of the study was to evaluate the utility of a Petrifilm-based on-farm culture system when used to make selective antimicrobial treatment decisions on low somatic cell count cows $(<200,000$ cells $/ \mathrm{mL})$ at drying off. A total of 729 cows from 16 commercial dairy herds with a low bulk tank somatic cell count $(<250,000$ cells $/ \mathrm{mL})$ were randomly assigned to receive either blanket dry cow therapy (DCT) or Petrifilmbased selective DCT. Cows belonging to the blanket DCT group were infused with a commercial dry cow antimicrobial product and an internal teat sealant (ITS) at drying off. Using composite milk samples collected on the day before drying off, cows in the selective DCT group were treated at drying off based on the results obtained by the Petrifilm on-farm culture system with DCT + ITS (Petrifilm culture positive), or ITS alone (Petrifilm culture negative). Quarters of all cows were sampled for standard laboratory bacteriology on the day before drying off, at 3 to $4 \mathrm{~d}$ in milk (DIM), at 5 to 18 DIM, and from the first case of clinical mastitis occurring within 120 DIM. Multilevel logistic regression was used to assess the effect of study group (blanket or selective DCT) and resulting dry cow treatment (DCT + ITS, or ITS alone) on the risk of intramammary infection (IMI) at calving and the risk of a first case of clinical mastitis between calving and 120 DIM. According to univariable analysis, no difference was observed between study groups with respect to quarter-level cure risk and new IMI risk over the dry period. Likewise, the risk of IMI at calving and the risk of clinical mastitis in the first 120 DIM was not different between quarters belonging to cows in the blanket DCT group and quarters belonging to cows in the selective DCT group. The results of this study indicate that selective DCT based on results obtained by the Petrifilm on-farm culture
\end{abstract}

Received May 24, 2013.

Accepted September 9, 2013.

${ }^{1}$ Corresponding author: mcameron@upei.ca system achieved the same level of success with respect to treatment and prevention of IMI over the dry period as blanket DCT and did not affect the risk of clinical mastitis in the first $120 \mathrm{~d}$ of the subsequent lactation. Key words: selective dry cow therapy, Petrifilm, culture

\section{INTRODUCTION}

\section{Dry Cow Therapy Practices in North America}

In North America, the preferred mastitis control strategy during the dry period is the infusion of a long-acting intramammary antimicrobial product (dry cow therapy, DCT) in all quarters of all cows. This practice, known as blanket DCT (BDCT), has been prescribed by the National Mastitis Council as part of their Recommended Mastitis Control Program (NMC, 2006). In the United States and Canada, uptake of BDCT is estimated at 72 and $88 \%$ of all dairy herds, respectively (USDA, 2008; Dufour et al., 2012). The function of DCT in mastitis control is 2-fold: (1) the cure of IMI present at drying off and (2) the prevention of new IMI in the early dry period. Historically, BDCT has played an important role in the overall reduction in the prevalence of contagious mastitis pathogens, and a consequential reduction in bulk tank SCC (BTSCC; Hillerton et al., 1995; Bradley, 2002; Ruegg, 2012). Since the promotion of BDCT in Canada in the late 1960s, Streptococcus agalactiae has been almost eradicated and the average provincial geometric-mean BTSCC in 2005 was 225,000 cells/mL (Olde Riekerink et al., 2006, 2010). In light of these changes in the epidemiology of mastitis, it is argued that the practice of BDCT by all herds is no longer required (Robert et al., 2006b; Huijps and Hogeveen, 2007; Rajala-Schultz et al., 2011). In support of this argument, there is growing concern regarding the impact of antimicrobial use in dairy production systems on the emergence of antimicrobial-resistant bacteria (Call et al., 2008; Oliver et al., 2011). In dairy production, antimicrobials are most frequently used for the purpose of treatment and 
prevention of mastitis (USDA, 2008; Saini et al., 2012), but the relationship between antimicrobial drug use and the development of resistance in bacteria is unclear (Call et al., 2008; Saini et al., 2012). Furthermore, studies examining the association between the use of DCT and antimicrobial resistance are sparse (RajalaSchultz et al., 2009). Nonetheless, antimicrobial drug use is considered a driving force for the development of resistance (Call et al., 2008), thus motivating research into alternative practices, which have the potential to limit their application.

\section{Internal Teat Sealants and Selective DCT}

Antimicrobials still play a vital role in dry period mastitis control. Dry cow intramammary antibiotics achieve high cure rates for susceptible pathogens (Gruet et al., 2001; Bradley and Green, 2004; Halasa et al., 2009a), and DCT remains effective in the prevention of new IMI by sensitive pathogens in the early dry period (Williamson et al., 1995; Berry and Hillerton, 2002b; Halasa et al., 2009b). Nevertheless, new IMI still occur despite DCT when the causative pathogens are nonsusceptible, or in the late dry period when antibiotic levels have fallen below the minimum inhibitory concentration (Oliver et al., 1990; Bradley and Green, 2000). Obstacles to the prevention of new IMI during the dry period can be overcome by the addition of an internal teat sealant (ITS) to the dry cow protocol. Internal teat sealants are a nonantimicrobial alternative to DCT for the prevention of IMI during the nonlactating period, and the effectiveness of ITS is well supported in the literature (Berry and Hillerton, 2002a; Huxley et al., 2002; Sanford et al., 2006a). In studies that have compared ITS to DCT in quarters uninfected at drying off, ITS performed just as well as DCT with respect to the prevention of new IMI (Woolford et al., 1998; Sanford et al., 2006a), suggesting that ITS can be used alone in the absence of IMI at the end of lactation. Antibiotic treatment of cows at the end of lactation based on IMI status is a dry period mastitis control strategy known as selective DCT (SDCT). The addition of an ITS to an SDCT protocol ensures that all quarters have some protection against new IMI, thus reducing the necessity for the prophylactic use of antimicrobials over the nonlactating period.

\section{Selection Procedures for DCT}

Although previous research supports the use of ITS alone in uninfected quarters, failing to treat an infected quarter with DCT results in financial losses (Berry et al., 2004). Therefore, an accurate selection method is required to correctly identify quarters free of IMI at drying off (Huxley et al., 2002; Robert et al., 2008; Torres et al., 2008). Selection procedures based on standard bacteriological culture (Robinson et al., 1988; Browning et al., 1990, 1994), SCC and clinical mastitis history (Rindsig et al., 1978; Torres et al., 2008; Rajala-Schultz et al., 2011), the California mastitis test (Rindsig et al., 1978; Sanford et al., 2006b; Bhutto et al., 2012), and $N$-acetyl- $\beta$-D-glucosaminidase (NAGase; Hassan et al., 1999) have been described in the literature with varying degrees of accuracy. The most commonly used selection method is based on monthly SCC, which has a reported sensitivity of $70 \%$ and specificity of $63 \%$ (Torres et al., 2008). The Petrifilm-based on-farm culture system is an easy-to-interpret, accurate, and quick diagnostic tool that enables dairy producers to culture milk directly on the farm and obtain results within $24 \mathrm{~h}$ (McCarron et al., 2009; Cameron et al., 2013). The Petrifilm-based on-farm culture system performed well when used to diagnose IMI in low-SCC cows at drying off, with a sensitivity of $85.2 \%$ and specificity of $73.2 \%$ (Cameron et al., 2013). The aim of the research outlined in this paper was to evaluate the use of a Petrifilm-based onfarm culture system in an SDCT program. The main objectives were to compare IMI risk at calving between quarters of cows receiving BDCT with the addition of an ITS and quarters of cows selectively treated based on the results of the Petrifilm on-farm culture system with DCT + ITS, or ITS alone. A comparison between the 2 study groups was also made regarding the risk of a first case of clinical mastitis between calving and 120 DIM of the subsequent lactation.

\section{MATERIALS AND METHODS}

\section{A Priori Sample Size Calculation}

Sample size calculations were based on a published prevalence of IMI at calving of approximately $20 \%$ when both DCT and ITS were used at drying off (Godden et al., 2003; Sanford et al., 2006a). With a significance level of $95 \%$ (2-sided) and a power of $80 \%$, it was determined that approximately 2,280 quarters ( 570 cows with 285 being in each group) would be required to detect a minimum change in risk of IMI at calving from 20 to $25 \%$ (margin of noninferiority of $5 \%$ ). This calculation assumes that quarters within a cow are independent, although research has shown interdependence of quarters with respect to IMI (Barkema et al., 1997; Berry and Meaney, 2006). To account for clustering of quarters within cows, an adjustment to the sample size was made using a published intraclass correlation coefficient $(\rho)$ of 0.20 (Barkema et al., 1997; Berry and Meaney, 2006), resulting in a sample size of 3,632 quarters (908 cows, with 454 per group). 


\section{Herd Selection}

To be considered for inclusion, herds were required to have an annual average of monthly BTSCC below 250,000 cells/mL over the last $12 \mathrm{mo}$ and be enrolled in a DHI program. A convenience sample of 16 Canadian dairy herds from Prince Edward Island $(\mathrm{n}=10)$ and Quebec $(\mathrm{n}=6)$ were enrolled in the randomized clinical trial. Eligible herds were selected based on willingness to adhere to the study protocol and proximity to the veterinary college in each province.

\section{Cow Selection}

Cow-level inclusion criteria consisted of monthly SCC below 200,000 cells $/ \mathrm{mL}$ on the last 3 milk tests before drying off, no clinical mastitis in the same time period, an expected dry period of 30 to $90 \mathrm{~d}$, no antibiotic treatment in the last $14 \mathrm{~d}$, and at least 3 functional quarters. On the day before drying off, eligible cows were subjected to a California mastitis test by the trained study personnel, and cows with a score of 2 or greater in any quarter were excluded from the trial.

Based on an analysis of the Canadian Bovine Mastitis Research Network cohort study, it was expected that $30 \%$ of cows would fail to meet the inclusion criteria for SCC less than 200,000 cells/mL (K. Reyher, Centre for Veterinary Epidemiological Research, University of Prince Edward Island, Charlottetown, PE, Canada, personal communication). Additional exclusions based on other criteria were estimated at $10 \%$ of cows. Therefore, a pre-exclusion sample of approximately 1,500 cows would be required to achieve the required sample size of 908 cows.

\section{Pre-Dry Sampling and Random Allocation to Treatment Groups}

Producers scheduled a dry-off day every other week to allow for cow enrollment and sample collection. On the day before drying off $(\mathrm{d}-1)$, single quarter-level milk samples were collected by the study personnel. Following premilking udder preparation as per farm protocol, teat ends were scrubbed clean with alcohol swabs and initial foremilk streams were discarded into a strip cup. Approximately $30 \mathrm{~mL}$ of milk was collected aseptically according to the procedures recommended in the Laboratory Handbook on Bovine Mastitis (NMC, 1999). Following sample collection $(\mathbf{D O}=$ dryoff sample), cows were randomly assigned to either the BDCT or the Petrifilm-based SDCT study group according to a randomization table unique to each herd, with a block size of 6 , thus randomizing 6 cows at a time ( 3 to BDCT and 3 to SDCT).

\section{On-Farm Bacteriological Culture and Treatment at Drying Off}

The study personnel set-up the Petrifilm-based onfarm culture system for cows assigned to SDCT. A composite sample was created by combining $5 \mathrm{~mL}$ of milk from each quarter sample into a new sample vial. A 3-mL aliquot of composite milk was added to $27 \mathrm{~mL}$ of sterile water to make a 1:10 dilution (McCarron et al., 2009). One milliliter of diluted milk was plated on an aerobic-count (AC) Petrifilm (3M Canada, London, ON, Canada) and incubated on farm at $35^{\circ} \mathrm{C}$ for $24 \mathrm{~h}$ in a TurboFan Hova-Bator (GQF Manufacturing Inc., Savannah, GA). The AC Petrifilm is a ready-made culture medium used for the detection of all aerobic bacteria and contains an indicator dye that facilitates colony enumeration. On the scheduled day of drying off (d 0), the Petrifilm was read by the producer and, in accordance with study protocol, cows were classified as positive if 5 or more colonies were present (equivalent to $\geq 50 \mathrm{cfu} / \mathrm{mL}$ of milk). Cows negative on Petrifilm were treated solely with an ITS composed of $65 \%$ bismuth subnitrate (Orbeseal; Pfizer Animal Health, Kirkland, QC, Canada) at drying off. Cows positive on Petrifilm were treated with a long-acting intramammary formulation of $500 \mathrm{mg}$ of ceftiofur hydrochloride (Spectramast DC; Pfizer Animal Health) followed by an ITS. Producers recorded the number of colonies present on the Petrifilm, as well as the treatment applied, to verify compliance with the study protocol. Cows in the BDCT group were infused with ceftiofur followed by an ITS in all 4 quarters, and again producers recorded the treatments given. All cows were dried off abruptly and dry cow treatments were administered by the producer or farm personnel immediately after the last milking. Teats were prepared aseptically before treatment, and were disinfected after treatment with a commercial teat dip.

\section{Postcalving Sampling and Record Keeping}

Postcalving quarter milk samples were aseptically collected by the producer between 3 and 4 DIM (PC1 $=$ postcalving sample 1) and by the study personnel between $\mathrm{d} 5$ and 18 DIM (PC2 $=$ postcalving sample 2) using the methods outlined for pre-dry-off sampling. At the time of sample collection, the producer and the study personnel recorded the occurrence of any postpartum disease (such as milk fever, mastitis, or retained placenta) and any given antibiotic treatment. The antibiotic treatment of a cow before the collection of the first postcalving sample resulted in the removal of the entire observation from the analyses. All postenrollment exclusions were enumerated and reported separately from preenrollment exclusions to allow for comparison between groups. 


\section{Clinical Mastitis Sampling}

Clinical mastitis cases occurring in participating cows in the first $120 \mathrm{~d}$ of the next lactation were recorded and sampled by the producer before treatment. Only the first clinical mastitis episode per quarter was considered in the analysis. Clinical mastitis was defined as visible changes in milk, with or without heat, swelling, or redness in the quarter, and with or without signs of systemic disease. Milk samples were collected aseptically and frozen on farm until collection by the study personnel during their visit every other week.

\section{Laboratory Bacteriological Culture}

Subsequent to collection, all milk samples were frozen at $-20^{\circ} \mathrm{C}$ before shipment to the Maritime Quality Milk research laboratory at the University of Prince Edward Island (Charlottetown, PE, Canada). Laboratory technicians were blinded to the results obtained by the Petrifilm on-farm culture system. Laboratory bacteriological culture was performed according to procedures outlined in the National Mastitis Council's Laboratory Handbook on Bovine Mastitis (NMC, 1999). A quarter was considered infected if $\geq 100 \mathrm{cfu} /$ $\mathrm{mL}$ of milk of any pathogenic organism of interest, except for CNS, were cultured. For CNS, a definition of $\geq 200 \mathrm{cfu} / \mathrm{mL}$ was used. These definitions are in accordance with the recent publication of characterization of IMI based on single-sample bacteriological testing (Dohoo et al., 2011b). Samples with 3 or more differing isolates were classified as contaminated, and isolation of Bacillus spp. was considered nonsignificant growth. However, when Staphylococcus aureus was identified in a contaminated sample, it was enumerated and the associated quarter was classified as infected (Reyher et al., 2011).

For the purpose of analysis, gram-negative bacteria, other than Escherichia coli and Klebsiella spp., were amalgamated into a grouping and encompassed Enterobacter spp., Proteus spp., Citrobacter spp., Pseudomonas spp., Serratia spp., Salmonella spp., Pasteurella multocida, and other nondifferentiated gram-negative bacteria. Coagulase-negative staphylococci were not differentiated beyond the group level, but if 2 phenotypically different species of CNS displayed growth on culture, each isolate was enumerated and reported.

\section{Definitions}

Postcalving IMI. Two definitions for postcalving IMI were applied, considering either PC1 alone, or both PC1 and PC2 interpreted in parallel. For the first definition, a quarter was considered to have an IMI if 1 or 2 pathogens were isolated in $\mathrm{PC} 1$. If $\mathrm{PC} 1$ was missing or contaminated, the observation was excluded from the analysis. For the second definition, a quarter was considered infected if either PC1 or PC2 displayed growth of 1 or 2 pathogens. In cases where one of the postcalving samples was missing or was classified as contaminated, the quarter infection status was determined solely by the results of the remaining sample. If both postcalving samples were contaminated or missing, the associated quarter was removed from the analysis.

Dry Period Cure. Dry period cure was determined at both the pathogen and quarter levels. A pathogen isolated in the DO was considered cured over the dry period if it was absent in both $\mathrm{PC} 1$ and $\mathrm{PC} 2$. A quarter was considered cured when a pathogen isolated in the $\mathrm{DO}$ was not recovered in either $\mathrm{PC} 1$ or $\mathrm{PC} 2$. If a quarter was infected with 2 pathogens at drying off, the absence of both pathogens in PC1 and PC2 was required for that quarter to be labeled cured. In cases where one, or both, of the postcalving samples were missing or contaminated, the associated quarter was excluded from the analysis.

New IMI. Two definitions of new IMI were investigated. According to both definitions, a quarter was defined as having a new IMI if a pathogen was cultured at calving that was not present in the DO. Therefore, both uninfected and infected quarters were considered at risk for new IMI during the dry period. For the first definition, only PC1 was considered. The second definition was based on parallel interpretation of $\mathrm{PC} 1$ and $\mathrm{PC} 2$; thus, if a pathogen was present in postcalving samples, but was not present in the DO, that quarter was considered newly infected over the dry period.

\section{Statistical Analysis}

Statistical analysis was performed using Stata/IC 11.0 (StataCorp, College Station, TX). The experimental unit for statistical analysis was the individual mammary quarter. Univariable analysis of the effect of study group was carried out using Fisher's exact test for the following outcomes: risk of IMI at drying off, risk of IMI at calving, risk for cure over the dry period, and risk of new IMI during the dry period.

Multilevel logistic regression models were applied to evaluate the effect of study group and treatment within the study group on (1) the risk of IMI at calving and (2) the risk of a first case of clinical mastitis between calving and 120 DIM. Random effects for cows and herds were incorporated in the models to account for clustering of quarters within cows, and cows within herds. The main predictor of interest, treatment group, was specified at the cow level, and was created by combining the variables study group (BDCT or SDCT) and 
subsequent treatment at drying off (DCT + ITS, or ITS alone), thus comprising 3 levels: BDCT, Petrifilm positive, and Petrifilm negative. Additional explanatory variables considered for inclusion in the models included region, herd size, housing type (tie-stall or freestall), season at calving, parity at calving $(2,3$, or $4+$ ), last recorded 24 -h milk yield (in $\mathrm{kg}$ ) before drying off, length of the dry period, quarter infection status at drying off as determined by standard bacteriologic culture, and quarter position (front or hind). The variable for season at calving was created using 3-mo intervals, such that winter was designated as December to February, spring as March to May, summer as June to August, and fall as September to November. All variables were explored using descriptive statistics and graphical analyses where appropriate. Continuous predictors were evaluated for linearity with the logit of the outcomes using a locally weighted scatter plot smoothed (lowess) curve.

The primary predictor of interest, treatment group, was forced into all models regardless of statistical significance. Intramammary infection status at drying off according to gold standard bacteriological culture was also retained in all models to control for the confounding effect of this variable on the association of treatment group with both the risk of IMI at calving and the risk of clinical mastitis in the subsequent lactation. Unconditional associations between the other explanatory variables and the outcomes were examined using simple univariable logistic regression and variables with $P$-values $<0.30$ were offered for inclusion in the multivariable models. A backward stepwise procedure was used to determine the final models, and all 2-way interactions involving the main predictor, treatment group, were evaluated. Of particular interest, an interaction between treatment group and quarter infection status at drying off as determined by standard bacteriologic culture was created to examine the effects of a false-negative and a false-positive Petrifilm result. Significance was declared at a $P<0.05$, but variables were retained in the models with $P<0.10$, or if they were involved in a significant 2 -way interaction. Once the final models were reached, the fit was evaluated by examination of residual plots (Dohoo et al., 2009).

\section{RESULTS}

\section{Cow Enrollment and Descriptive Statistics}

During the cow enrollment period of July 2009 to September 2010, a total of 1,584 cows from the 16 participating herds entered the dry period. The number of cows dried off per farm ranged from 42 to 263 , with a median of 81 cows. Details of cow enrollment and a flowchart of study units can be found in Figure 1. The most common reason for exclusion from the trial was high SCC (504/855; 58.9\% of exclusions), followed by an anticipated long or short dry period (249/855; $29.1 \%$ of exclusions). The addition of the California mastitis test to the enrollment criteria resulted in only 7 additional cows being excluded from the trial and, therefore, provided little information beyond what was obtained using selection criteria based on SCC and clinical mastitis history. The proportion of cows per farm eligible for inclusion ranged from $28.3 \%(15 / 53)$ to $69.4 \%(145 / 209)$, and ultimately a total of $729(46.0 \%)$ cows were enrolled in the trial. Of these cows, 369 (1,476 quarters) were assigned to the BDCT group and 360 (1,440 quarters) were assigned to the SDCT group (Figure 1). Postenrollment exclusions and attrition resulted in the loss of 126 cows for the following reasons: no postcalving sample was collected $(\mathrm{n}=9)$, death $(\mathrm{n}$ $=10)$, sold before calving $(\mathrm{n}=11)$, abortion $(\mathrm{n}=2)$, not pregnant $(\mathrm{n}=2)$, an actual dry period greater than $90 \mathrm{~d}$ or shorter than $30 \mathrm{~d}(\mathrm{n}=51)$, other antibiotic treatment before postcalving sample collection $(\mathrm{n}=$ 40), and contamination of all postcalving milk samples $(\mathrm{n}=1)$. Sixteen cows that received antibiotic treatment before sample collection were treated for mastitis $(\mathrm{BDCT}=7$ cows; SDCT $=9$ cows $)$. An additional 114 quarters were excluded due to contamination, and 11 quarters were nonlactating. No significant differences were observed between study groups with respect to postenrollment exclusion or attrition. Thus, 1,157 BDCT group quarters $(\mathrm{n}=305$ cows $)$ and 1,130 SDCT quarters $(\mathrm{n}=298$ cows) were available for analysis (Figure 1). The cow-level prevalence of IMI at drying off in the SDCT group according to Petrifilm on-farm culture was $54.4 \%(162 / 298)$. Therefore, at a Petrifilm treatment threshold of $\geq 50 \mathrm{cfu} / \mathrm{mL}, 45.6 \%(136 / 298)$ of the cows were classified as uninfected and did not receive a long-acting intramammary antibiotic at drying off. Descriptive statistics for the cows included in the final analysis can be found in Table 1 .

\section{Risk of IMI at Drying Off and Postcalving}

The standard bacteriological culture results from quarter-level milk samples collected at the end of lactation and at calving are shown in Tables 2 and 3. Despite random allocation into study groups, the proportion of quarters with an IMI at drying off was higher in the SDCT group than in the BDCT group, but this difference was only borderline significant [BDCT: $12.4 \%$ (95\% CI: $10.5,14.3 \%$ ) vs. SDCT: $15.1 \%$ (95\% CI: 13.0 , $17.2 \%) ; P=0.054]$. In the SDCT group, a false-negative Petrifilm result occurred in 20 cows and as a result, 23 quarters were misclassified as negative and did not 
Table 1. Descriptive statistics for cows enrolled in a randomized clinical trial to evaluate the use of a Petrifilm-based on-farm culture system in a selective dry cow therapy (SDCT) program

\begin{tabular}{|c|c|c|c|c|c|c|c|c|}
\hline \multirow[b]{2}{*}{ Item } & \multicolumn{4}{|c|}{$\mathrm{BDCT}^{1}(\mathrm{n}=305)$} & \multicolumn{4}{|c|}{$\mathrm{SDCT}^{2}(\mathrm{n}=298)$} \\
\hline & Number & Mean & $\mathrm{SD}$ & Range & Number & Mean & $\mathrm{SD}$ & Range \\
\hline Dry period length & & 59 & 11 & $30-90$ & & 59 & 11 & $32-89$ \\
\hline \multicolumn{9}{|l|}{ Parity at calving } \\
\hline 2 & 145 & & & & 144 & & & \\
\hline 3 & 77 & & & & 64 & & & \\
\hline Winter & 77 & & & & 69 & & & \\
\hline Spring & 56 & & & & 54 & & & \\
\hline Summer & 79 & & & & 78 & & & \\
\hline Fall & 93 & & & & 97 & & & \\
\hline
\end{tabular}

${ }^{1}$ Blanket dry cow therapy (BDCT) = cows received BDCT plus internal teat sealant (ITS) at drying off.

${ }^{2}$ Cows were selectively treated based on Petrifilm on-farm culture results with dry cow antibiotic and ITS, or ITS alone, at drying off.

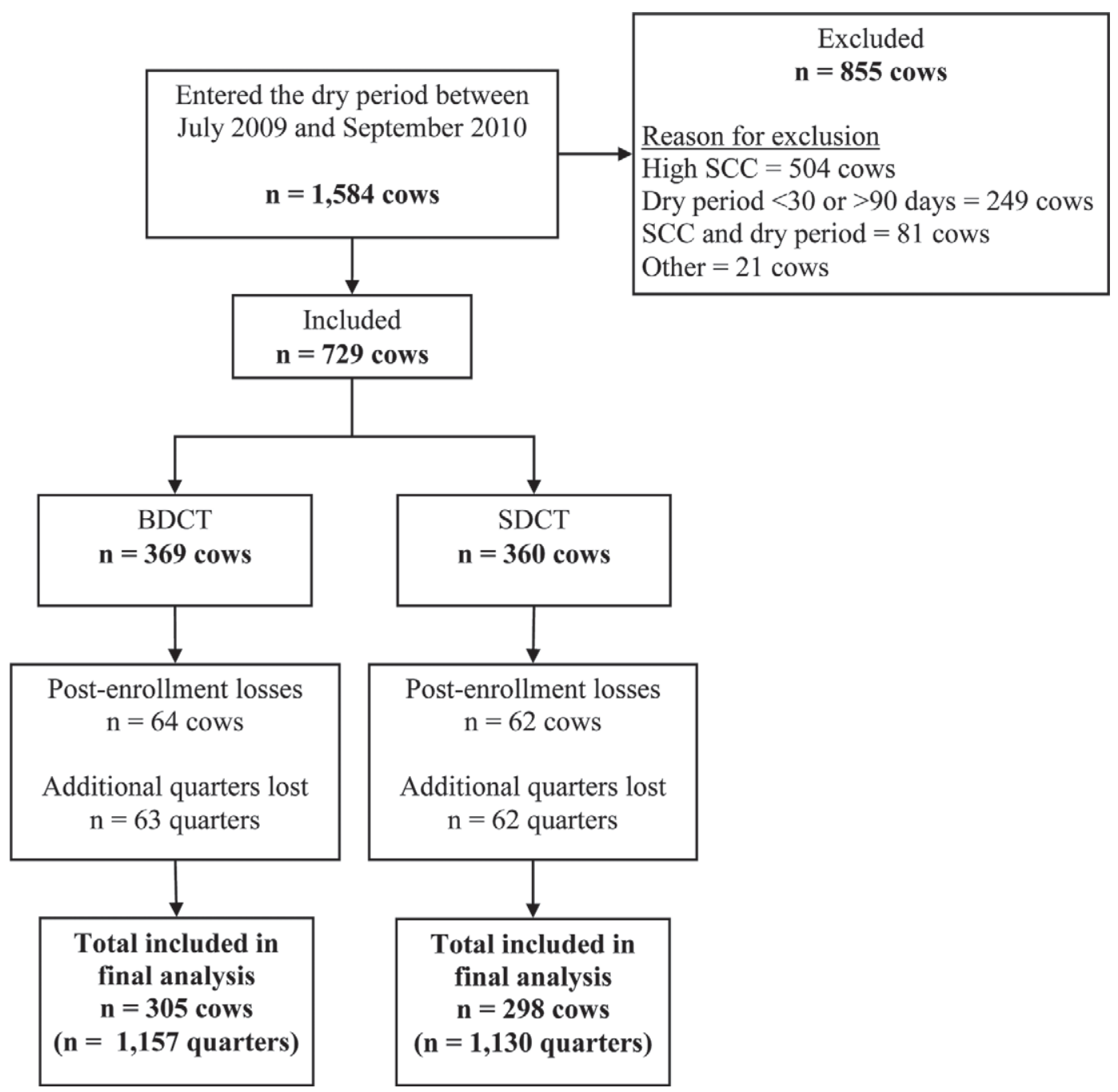

Figure 1. Enrollment of cows in the randomized clinical trial to evaluate the use of a Petrifilm-based on-farm culture system in a selective dry cow therapy program (BDCT $=$ cows receiving blanket dry cow therapy plus internal teat sealant at drying off; SDCT $=$ cows selectively treated based on Petrifilm on-farm culture results with dry cow antibiotic and internal teat sealant, or internal teat sealant alone, at drying off). 
Table 2. Prevalence of IMI and bacterial species isolated on the day before drying off in quarters receiving blanket dry cow therapy (BDCT) plus internal teat sealant (ITS) and quarters selectively treated based on Petrifilm on-farm culture results with dry cow antibiotic (dry cow therapy, DCT) and ITS, or ITS alone (selective dry cow therapy, SDCT) ${ }^{1}$

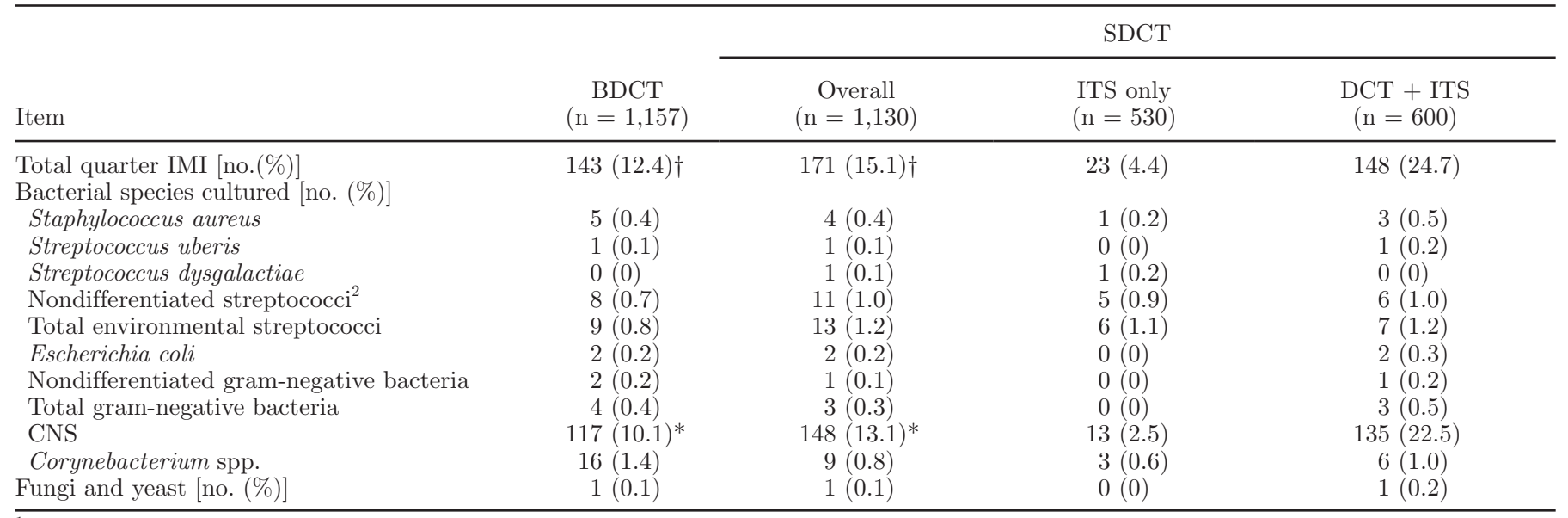

${ }^{1}$ Definition of IMI: all pathogens except CNS $\geq 100 \mathrm{cfu}$ per $1.0 \mathrm{~mL}$ of milk; CNS $\geq 200 \mathrm{cfu}$ per $1.0 \mathrm{~mL}$ of milk (Dohoo et al., $2011 \mathrm{~b}$ ).

${ }^{2}$ Including Enterococcus spp.; does not include Streptococcus agalactiae.

$\dagger P<0.10 ;{ }^{*} P<0.05 ; P$-values from univariable analysis.

receive DCT at drying off. Out of the group of cows (n $=162$ ) that cultured positive on Petrifilm, $67.3 \%$ had at least 1 quarter with an IMI at drying off according to standard culture.

Following calving, the prevalence of IMI was not different between study groups, whether postcalving IMI status was determined by the first postcalving sample [BDCT: $11.1 \%$ (95\% CI: 9.0, 13.2\%) vs. SDCT: $10.6 \%(95 \%$ CI: $8.6,12.7 \%) ; P=0.77$ or by parallel interpretation of both postcalving samples [BDCT: $15.3 \%$ (95\% CI: $13.2,17.4 \%)$ vs. SDCT: $15.8 \%$ (95\%
CI: $13.7,18.0 \%) ; P=0.72$. As the second definition resulted in higher statistical power and represented a more liberal definition of postcalving IMI, it was examined as the outcome in the multivariable model. Coagulase-negative staphylococci were the most commonly isolated pathogens at all sampling periods. The next-most-common pathogens isolated at drying off were Corynebacterium spp. and environmental streptococci, followed by Staph. aureus. After calving, environmental streptococci and Staph. aureus were the next-most-prevalent pathogens.

Table 3. Prevalence of IMI and bacterial species isolated within $18 \mathrm{~d}$ after calving in quarters receiving blanket dry cow therapy (BDCT) plus internal teat sealant (ITS) and quarters selectively treated based on Petrifilm on-farm culture results with dry cow antibiotic (dry cow therapy, DCT) and ITS, or ITS alone (selective dry cow therapy, SDCT) ${ }^{1}$

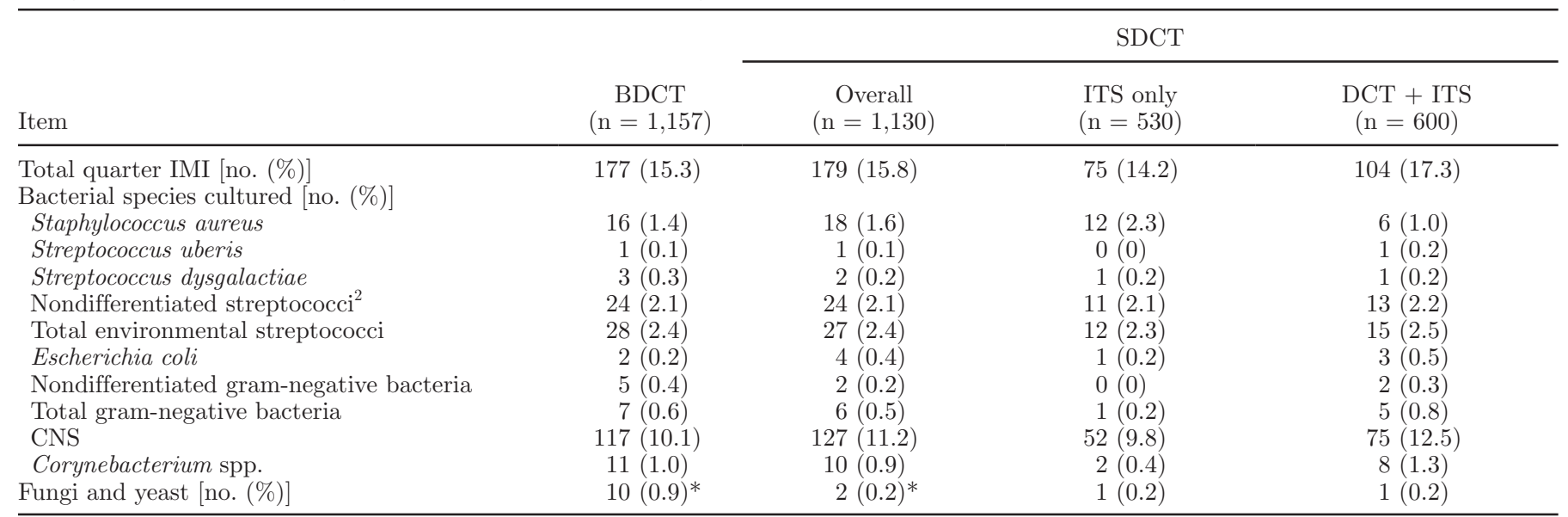

${ }^{1}$ Definition of IMI: all pathogens except CNS $\geq 100$ cfu per $1.0 \mathrm{~mL}$ of milk; CNS $\geq 200$ cfu per $1.0 \mathrm{~mL}$ of milk (Dohoo et al., $2011 \mathrm{~b}$ ).

${ }^{2}$ Including Enterococcus spp.; does not include Streptococcus agalactiae.

${ }^{*} P<0.05 ; P$-values from univariable analysis. 


\section{Cure Risk Over the Dry Period}

Quarter-level cure risk over the dry period was high and was not different between study groups [BDCT: 84.5\% (95\% CI: $76.0,90.9 \%$ ); SDCT: $89.0 \%$ (95\% CI: $81.9,94.0 \%) ; P=0.33]$. No significant difference was observed in species-specific cure risks between quarters that received BDCT and quarters that received SDCT. The cure risk for Staph. aureus in the BDCT group was $100 \%(5 / 5)$, but in the SDCT group, the cure risk was $75 \%(3 / 4)$. In the SDCT group, the quarter infected with Staph. aureus that failed to cure belonged to a cow that was misdiagnosed by the Petrifilm on-farm culture system and, therefore, that quarter did not receive DCT at drying off. The same was true for a SDCT-group quarter that remained infected with Streptococcus dysgalactiae and 1 quarter that remained infected with CNS from drying off to calving. However, the overall apparent self-cure risk for quarters misdiagnosed by the Petrifilm on-farm culture system was $87.0 \%(20 / 23)$. Pathogens isolated from the quarters with spontaneous cure were CNS $(\mathrm{n}=12)$, nondifferentiated streptococci $(\mathrm{n}=5)$, and Corynebacterium spp. $(\mathrm{n}=3)$.

\section{New IMI Risk Over the Dry Period}

When new IMI risk was examined using only the first postcalving sample, the results were similar to those obtained using both postcalving samples (results not shown). Because analyses using both postcalving samples resulted in greater power, and a more liberal definition of new IMI, only those results are presented.
The pathogen-specific and quarter-level new IMI risks are presented in Table 4. Overall, no significant difference was observed between quarters that received BDCT and quarters under SDCT based on Petrifilm results. More quarters with new IMI were caused by fungi and yeast in the BDCT group than in the SDCT group $(0.9 \%$ vs. $0.2 \% ; P=0.04)$. The majority of new infections were caused by CNS, followed by environmental streptococci and Staph. aureus.

\section{Unconditional Analyses and Final Multilevel Model for the Risk of IMI at Calving}

Unconditional associations between independent variables and the probability of IMI at calving are presented in Table 5. Significantly associated with the risk of IMI postcalving were IMI status at drying off according to standard culture, season at drying off, parity at calving, and quarter position. Twenty-fourhour milk yield on the last test before drying off was borderline significant [odds ratio $(\mathbf{O R})=1.02(95 \% \mathrm{CI}$ : $1.00,1.04 \%)]$.

The results of the final multivariable logistic model are presented in Table 6 . In the final model, treatment group was not significantly associated with the probability of IMI at calving $(P=0.95)$. Similarly, the following independent variables were not associated with the risk of IMI at calving and were excluded from the final model: region, herd size, housing type, 24-h milk yield on the last test, parity at calving, and length of the dry period. Neither IMI status at drying off according to standard bacteriological culture $(P=0.29)$

Table 4. Species-specific and overall apparent new IMI risk over the dry period for quarters receiving blanket dry cow therapy (BDCT) plus internal teat sealant (ITS) and quarters selectively treated based on Petrifilm on-farm culture results with dry cow antibiotic (dry cow therapy, DCT) and ITS, or ITS alone (selective dry cow therapy, SDCT)

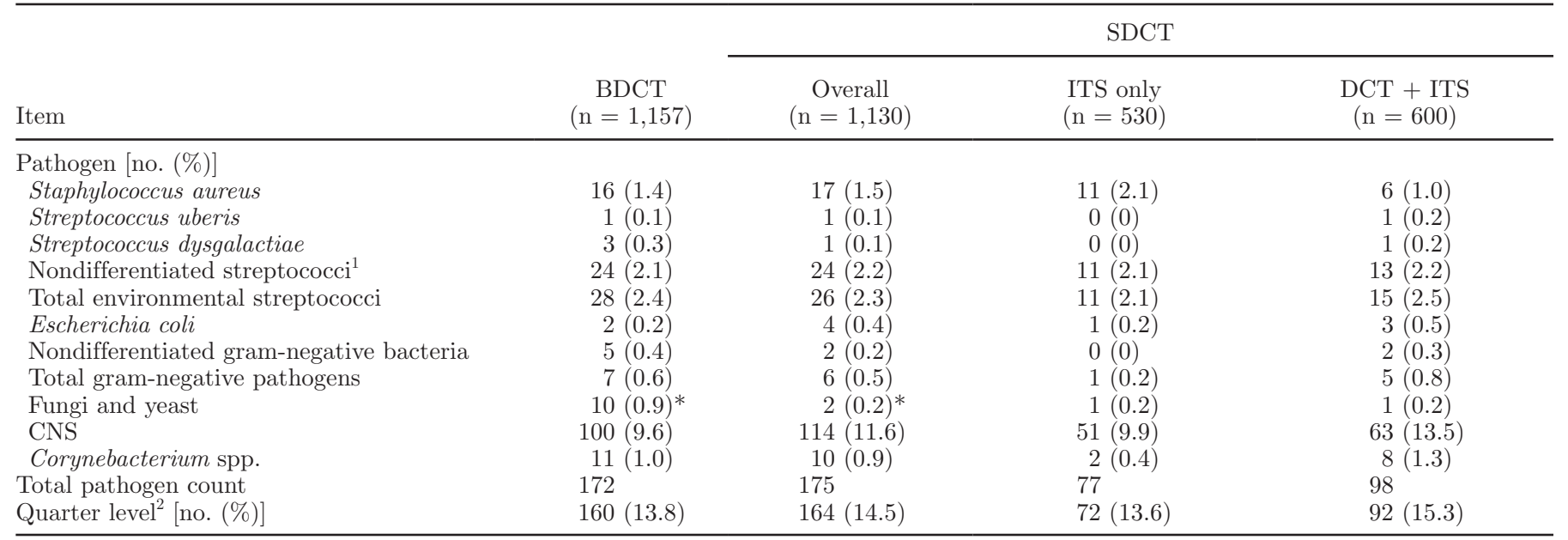

${ }^{1}$ Including Enterococcus spp.; does not include Streptococcus agalactiae.

${ }^{2} \mathrm{~A}$ quarter may have been infected with up to 2 different pathogens.

${ }^{*} P<0.05 ; P$-values from univariable analysis. 
Table 5. Unconditional associations between independent variables and the risk of IMI at calving for quarters receiving blanket dry cow therapy (BDCT) plus internal teat sealant (ITS) and quarters selectively treated based on Petrifilm on-farm culture results with dry cow antibiotic (dry cow therapy, DCT) and ITS, or internal teat sealant alone (selective dry cow therapy, SDCT)

\begin{tabular}{|c|c|c|c|}
\hline Variable & $\begin{array}{l}\text { No. of } \\
\text { quarters }\end{array}$ & $\begin{array}{c}\text { Proportion } \\
\text { with IMI (\%) }\end{array}$ & $P$-value \\
\hline Treatment group & & & 0.32 \\
\hline BDCT & 1,157 & 15.3 & \\
\hline Petrifilm negative & 530 & 14.2 & \\
\hline Petrifilm positive & 600 & 17.3 & \\
\hline IMI at drying off & & & 0.018 \\
\hline Yes & 314 & 20.1 & \\
\hline No & 1,973 & 14.9 & \\
\hline Region & & & 0.30 \\
\hline Prince Edward Island, Canada & 1,409 & 16.2 & \\
\hline Quebec, Canada & 878 & 14.6 & \\
\hline Herd size & $\mathrm{OR}=1.00^{1}$ & & 0.22 \\
\hline Housing type & & & 0.16 \\
\hline Freestall & 1,866 & 16.1 & \\
\hline Tie-stall & 421 & 13.3 & \\
\hline Season at calving & & & 0.003 \\
\hline Winter & 571 & 11.7 & \\
\hline Spring & 427 & 13.3 & \\
\hline Summer & 598 & 18.6 & \\
\hline Fall & 691 & 17.5 & \\
\hline Parity at calving & & & 0.048 \\
\hline 2 & 1,107 & 14.8 & \\
\hline 3 & 528 & 18.9 & \\
\hline $4+$ & 652 & 14.1 & \\
\hline 24-h milk yield & $\mathrm{OR}=1.02^{1}$ & & 0.065 \\
\hline Length of dry period & $\mathrm{OR}=1.01^{1}$ & & 0.29 \\
\hline Quarter position & & & 0.030 \\
\hline Front & 1,149 & 13.9 & \\
\hline Hind & 1,138 & 17.2 & \\
\hline
\end{tabular}

${ }^{1}$ Odds ratio (OR) from simple logistic regression.

nor the interaction term between infection status and treatment group $(P=0.36)$ was significant. Quarter position was a significant predictor in the model, with hind quarters having higher odds of IMI $[\mathrm{OR}=1.36$ (95\% CI: 1.05, 1.75\%)]. Season at calving was also significant, with quarters belonging to cows calving in the summer and the fall having a higher likelihood of IMI $[\mathrm{OR}=1.95(95 \% \mathrm{CI}: 1.21,3.15 \%) ; \mathrm{OR}=1.75(95 \%$ CI: $1.10,2.78 \%$ ), respectively] than quarters of cows calving in the winter (referent category). Evaluation of residual plots did not indicate a problem with the fit of the final model.

\section{Risk of Clinical Mastitis in the First 120 Days of Lactation}

Clinical mastitis data were available for 11 herds, for a total of 620 enrolled cows (2,480 quarters). Prior to analysis, several cows were excluded for the following reasons: death $(\mathrm{n}=9)$, sold $(\mathrm{n}=8)$, abortion $(\mathrm{n}=$ $1)$, not pregnant $(n=2)$, dry period greater than 90 $\mathrm{d}$ or shorter than $30 \mathrm{~d}(\mathrm{n}=37)$, and other antibiotic treatment $(\mathrm{n}=37)$. An additional 9 quarters were nonlactating, and 70 quarters were removed due to con- tamination of the sample collected at drying off. Thus, 525 cows (2,025 quarters) were used in the analysis: 264 (1,019 quarters) belonging to the BDCT group and 261 (1,006 quarters) belonging to the SDCT group.

In total, there were 45 reported cases of clinical mastitis, with 24 cases occurring in the BDCT group and 21 cases occurring in the SDCT group. The overall quarter-level incidence of clinical mastitis in the first $120 \mathrm{~d}$ of lactation was $2.2 \%(45 / 2,025)$ and at the cow level, the incidence was $7.4 \%(39 / 525)$. The most commonly isolated pathogens were E. coli $(9 / 45)$, CNS $(8 / 45)$, and Staph. aureus (7/45). A diagnosis of no microbial growth was made in $22.2 \%(10 / 45)$ of the samples. In the final multivariable logistic model, neither treatment group $(P=0.58)$ nor infection status at drying off based on standard culture $(P=0.22)$ were statistically significant. No association between the other tested variables and the risk of clinical mastitis was found. Evaluation of residual plots did not indicate a problem with the fit of the final model.

\section{DISCUSSION}

This is the first study evaluating the utility of a Petrifilm-based on-farm culture system in a SDCT pro- 
Table 6. Final multilevel model for the risk of IMI postcalving in quarters receiving blanket dry cow therapy (BDCT) plus internal teat sealant (ITS) and quarters selectively treated based on Petrifilm on-farm culture results with dry cow antibiotic (dry cow therapy, DCT) and ITS, or ITS alone (selective dry cow therapy, SDCT)

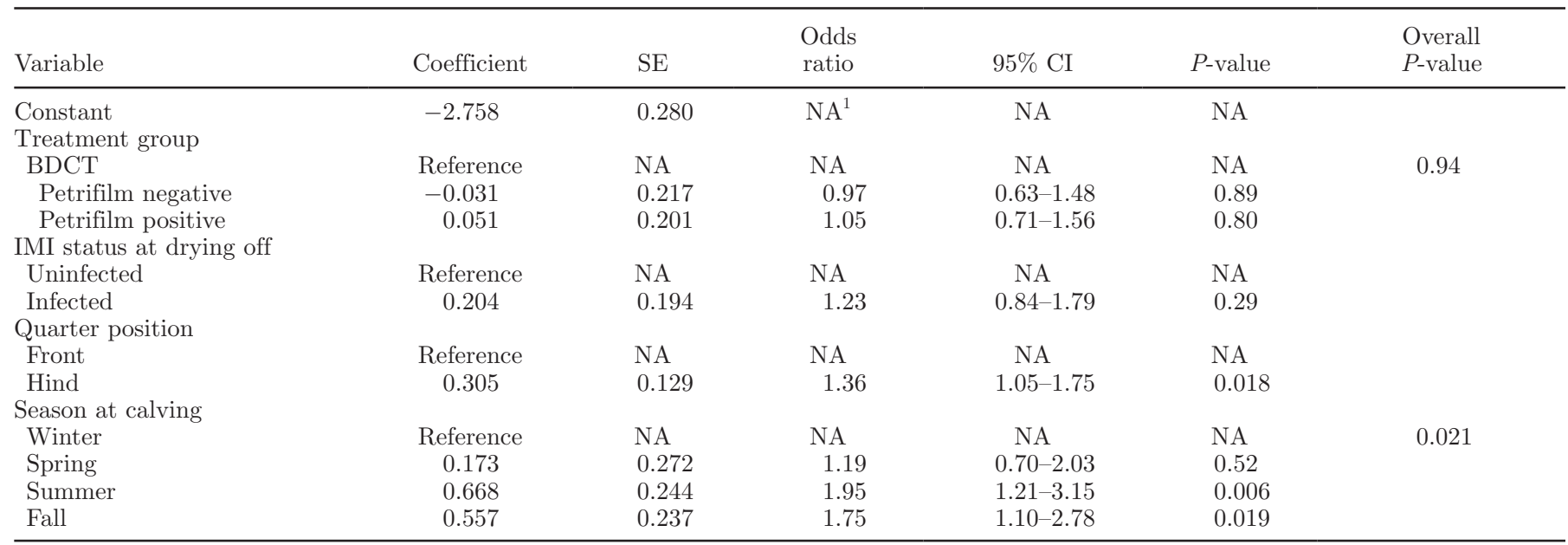

${ }^{1} \mathrm{NA}=$ not applicable.

gram. Considering that BDCT remains the mainstay of dry period mastitis control in North America, the acceptance of SDCT by dairy producers necessitates a cautious approach, particularly in the introductory phase. As a result, a tiered approach to the selection protocol was used, creating a starting point of lowBTSCC herds and low-SCC cows and this must be taken into account when interpreting the results of the study. Following the procedures outlined in the current study, $46.0 \%$ of the cows dried off during the enrollment period met the inclusion criteria and, after accounting for postenrollment exclusions, $45.6 \%$ of cows assigned to SDCT cultured negative on farm and did not receive dry cow antibiotics. Therefore, when the Petrifilm onfarm culture system was applied at the cow level, a total reduction in DCT of $21 \%$ was realized.

\section{Risk of IMI at Calving}

According to the present study, the selective antibiotic treatment of low-SCC cows at the end of lactation based on Petrifilm on-farm culture results was just as effective in the treatment and prevention of IMI during the dry period as BDCT in herds with a low BTSCC $(<250,000$ cells $/ \mathrm{mL})$. The success of a SDCT program depends greatly on the ability of the selection protocol to accurately identify cows with an IMI at the time of drying off so that DCT can be applied judiciously, while minimizing the risk of failing to treat an infected cow. The Petrifilm on-farm culture system enabled the detection of cows with an IMI at the end of lactation and as a result, SDCT based on Petrifilm culture results achieved the same level of success as BDCT with regard to infection status at calving.
Exploration of an interaction between treatment group and IMI status at drying off according to standard bacteriological culture demonstrated that misclassification of cows by the Petrifilm on-farm culture system did not have a negative effect on the outcome at calving. With respect to misdiagnosis, of greatest concern would be a false-negative Petrifilm result at the cow level, resulting in an infected quarter not receiving the therapeutic benefits of DCT. In the current study, only 3 infected quarters belonging to cows with a falsenegative Petrifilm result remained infected with the same pathogen at calving, including 1 quarter chronically infected with Staph. aureus. Despite misdiagnosis at drying off, $87 \%(20 / 23)$ of infected and untreated quarters experienced an apparent self-cure over the dry period. Most importantly, the occurrence of a quarterlevel false-negative diagnosis was infrequent (13.5\%; $23 / 171$ quarters) and, therefore, did not result in an increase in the risk of IMI postcalving when compared with BDCT.

In contrast to a false-negative diagnosis, the consequence of a false-positive diagnosis would be the unnecessary antimicrobial treatment of quarters without an IMI at drying off and is less of a concern from a clinical standpoint. A limitation of the on-farm culture system is the inability of the Petrifilm to distinguish nonsignificant growth and contamination from IMI. The AC Petrifilm does not allow for species identification, making it impossible to determine if colonies represent a single or multiple species, or if growth is that of a recognized mastitis pathogen. Strict aseptic technique must be applied when collecting samples for use with the on-farm culture system to minimize the false-positive rate and the unnecessary antimicro- 
bial treatment of mammary quarters. The Petrifilm on-farm culture system was applied at the cow level because, for the majority of SDCT programs, this is the level at which treatment decisions are made. As a result, many uninfected quarters were treated because they belonged to a cow that had at least 1 infected quarter. Application of the on-farm culture system at the quarter level would result in a greater reduction in unnecessary antibiotic use, but would require individual quarter culture, which, in turn, would demand more materials and labor. The literature has shown interdependence of quarters for the acquisition of new IMI during the dry period, leading to the recommendation that DCT be applied to all quarters of a cow, as opposed to only the affected quarter(s) (Browning et al., 1990; Berry et al., 2003; Robert et al., 2006a). However, quarter interdependence toward new IMI may be reduced when effective prevention strategies are in place or when the risk of cross-quarter contamination is low (Barkema et al., 1997; Berry et al., 2003; Robert et al., 2006a).

\section{Prevalence of IMI at Drying Off}

The prevalence of IMI at drying off was low, reflecting the nature of the herds and the cows meeting the inclusion criteria (i.e., low BTSCC at the herd level, and low monthly SCC before drying off at the cow level). According to results obtained from the Canadian National Cohort of Dairy Farms (NCDF) from milk samples collected between 4 and 2 wk before drying off, and again between 2 wk and drying off $(\mathrm{n}=1,681$ cows originating from 90 herds), the prevalence of IMI at the quarter level was $66.3 \%$, and the majority of these infections were caused by minor pathogens $(60.2 \%)$ [D. Haines (Université de Montréal, Saint-Hyacinthe, QC, Canada), personal communication (January 15, 2013)]. The farms recruited in the NCDF were chosen to represent a uniform distribution of BTSCC (from $\leq 150,000$ cells $/ \mathrm{mL}$ to $>300,000$ cells $/ \mathrm{mL}$ ) and therefore included herds with higher BTSCC than found in the current study. In the NCDF, Staph. aureus was the most commonly isolated major pathogen, and the third-mostcommonly isolated pathogen overall, found in $4.2 \%$ of quarters before drying off [D. Haines (Université de Montréal, Saint-Hyacinthe, QC, Canada), personal communication (January 15, 2013)]. In the present study, Staph. aureus was the fourth-most-commonly isolated pathogen at drying off, but the prevalence at the quarter level was only $0.4 \%$ (9 quarters positive with Staph. aureus out of 2,287 quarters cultured). Staphylococcus aureus remains an important mastitis pathogen in the Canadian dairy industry (Reyher et al., 2011). Lactational cures rates for Staph. aureus are generally
$<50 \%$ at the quarter level (Roy and Keefe, 2012). As a result, it is common to treat cows infected with Staph. aureus at drying off, where cure rates of up to $77 \%$ have been reported (Halasa et al., 2009a). For the present study, inclusion criteria at the herd level included low BTSCC because the likelihood of high prevalence of Staph. aureus and other major contagious pathogens would be low. In herds where major contagious pathogens dominate and are prevalent, the practice of BDCT remains an important control measure.

In the present study, CNS were the most frequently isolated pathogens in both study groups at all sampling points. Coagulase-negative staphylococci are considered to be an emerging mastitis pathogen, as they are the most common cause of IMI in many countries; however, the importance of CNS as a group of mastitis pathogens remains unclear (Pyörälä and Taponen, 2009; Schukken et al., 2009; Reyher et al., 2012). Some studies have shown that CNS infection can be protective against major pathogen infection during lactation and over the dry period (Rainard and Poutrel, 1988; Østerås and Sandvik, 1996; Green et al., 2005), whereas other studies have declared an increase in susceptibility to major pathogens when a CNS infection is established (Hogan et al., 1988; Berry and Hillerton, 2002a,b). Until further research establishes the true nature of CNS infection, the most prudent recommendation would be to treat all cases of CNS IMI present at the end of lactation. However, according to the results of the current study, leaving a quarter infected with CNS untreated at drying off may not necessarily result in a negative outcome at calving, as an apparent self-cure rate of $92.3 \%$ $(12 / 13)$ for CNS was achieved in untreated quarters that were misdiagnosed at drying off by the Petrifilm on-farm culture system.

\section{Cure Risk Over the Dry Period}

Cure risks over the dry period were high in both study groups, and were similar to those reported in other studies in quarters receiving DCT + ITS (Godden et al., 2003; Newton et al., 2008; Bradley et al., 2011). In the final multivariable model, IMI status at drying off according to standard bacteriological culture was not associated with the risk of IMI postcalving. Dry cow antibiotic therapy was, therefore, effective in eliminating IMI in both study groups, and more specifically for the SDCT group, DCT was applied in a manner that successfully eliminated IMI to the same degree as BDCT. A high cure risk was maintained in infected quarters that did not receive DCT as a result of a false-negative Petrifilm result. High apparent selfcure rates in cows with low SCC at drying off have been reported in other studies (Harmon et al., 1986; Huxley 
et al., 2002; Bradley et al., 2010). In the current study, the low-SCC nature of the cows might indicate that some of the pathogens isolated at drying off may have represented teat canal infections that were more easily eliminated.

\section{New IMI Risk Over the Dry Period}

The risk of new IMI over the dry period was low, and was similar between BDCT and SDCT groups. A notable aspect of this study was the application of an ITS in all quarters of all cows, as opposed to reserving ITS for quarters of cows selected not to receive DCT. The use of an ITS in all quarters of all cows as a tool for the prevention of IMI during the dry period is well supported by the literature (Sanford et al., 2006a; Newton et al., 2008; Bradley et al., 2010). The use of an ITS alone to prevent IMI in quarters uninfected at the end of lactation is also established by prior studies that have shown that an ITS is just as effective as DCT in the prevention of IMI in quarters that are bacteriologically negative at drying off (Woolford et al., 1998; Sanford et al., 2006a). However, when ITS are used alone, strict asepsis and a partial insertion technique are recommended. Internal teat sealants contain no antibiotic; therefore, it is essential to minimize the risk of accidental introduction of bacteria during infusion. In the present study, all nonlactating cow treatments were administered by the producers. The producers were able to maintain asepsis during infusion of ITS and, as a result, the risk of new IMI was not higher in quarters that received ITS as a sole treatment at drying off. Interestingly, the risk of new IMI caused by fungi and yeast, typically associated with poor aseptic technique (NMC, 1999) was numerically higher in the quarters receiving $\mathrm{BDCT}$; however, the numbers were too small to draw definitive conclusions.

In comparison to the results of the current study, other studies examining SDCT have reported a higher risk of new IMI in selectively treated cows than in cows receiving BDCT (Rindsig et al., 1978; Berry and Hillerton, 2002b). In the earlier studies, cows not receiving DCT were left unprotected during the dry period. It has been shown that up to $23.4 \%$ of teats have not formed a protective keratin plug within the streak canal by 6 wk dry (Dingwell et al., 2004). Mammary quarters lacking a functional keratin plug remain susceptible to infection, and as a result, the odds of new IMI in an open quarter is 1.7 times higher compared with a closed quarter (Dingwell et al., 2004). In the current study, the use of an ITS in all cows, and specifically in cows not infused with DCT, resulted in the protection of all quarters against new IMI over the dry period.

\section{Misclassification Bias}

In the current study, postcalving IMI status was modeled using an outcome based on parallel interpretation of milk samples collected between 3 and 4 DIM and between 5 and 18 DIM. Parallel interpretation of milk culture results has the benefit of increasing sensitivity to detect IMI over series interpretation or single-sample culturing (Dohoo et al., 2011a). Additionally, parallel interpretation minimized the loss of study units due to missing or contaminated samples. However, because IMI status was determined using samples collected postcalving, it is possible that infections detected in those samples represented infections that were acquired in the postcalving period. Consequently, the risk of IMI postcalving included not only the risk of IMI over dry period, but also the risk up to $18 \mathrm{~d}$ into the next lactation. In fact, the prevalence of IMI was higher when calculated using both postcalving samples than when only the first sample was considered. When considering only the first postcalving sample, which was collected between 3 to $4 \mathrm{~d}$ in lactation and would be more representative of IMI status at calving, the risk of IMI between study groups was not different. Lastly, because the same sampling protocol was used in both study groups, any misclassification bias resulting from the timing of the postcalving samples would be nondifferential; that is, the risk of misclassification error would be the same in both groups. Nondifferential misclassification errors bias the estimate of the OR toward the null; therefore, it is possible that a type II error (i.e., the false conclusion that study group did not affect the risk of IMI postcalving) occurred as a result of the sampling protocol used (Dohoo et al., 2009).

\section{Clinical Mastitis in the First 120 DIM}

Infections acquired during the dry period can be a cause of clinical mastitis in early lactation (Green et al., 2002, 2007). Therefore, prevention of IMI during the dry period can have the additional benefit of reducing clinical mastitis in early lactation and the associated negative effects on milk production and reproduction. In the current study, the risk of clinical mastitis in the first $120 \mathrm{~d}$ of lactation was the same between treatment groups. Furthermore, quarters negative on Petrifilm that did not receive DCT but were infused with only an ITS at drying off were not at increased risk for an episode of clinical mastitis in early lactation compared with quarters infused with DCT + ITS. The use of an ITS alone, and in combination with DCT, has been shown to be protective against clinical mastitis in early lactation by others (Godden et al., 2003; Sanford 
et al., 2006a; Newton et al., 2008). Overall, the risk of clinical mastitis was low; however, compliance of study participants with this portion of the study may have been incomplete; therefore, these results should be interpreted with caution due to the reduced sample size. Despite incomplete compliance regarding clinical mastitis reporting and sampling, no reason exists to believe that underreporting was greater in one study group.

\section{Association of Outcome with Other Predictors}

Although the main focus of this study was to compare Petrifilm-based SDCT to BDCT, the collection of additional data provided an opportunity to evaluate the effect of other factors on the risk of IMI at calving. According to the data, hind quarters were more likely to have an IMI postcalving than quarters located in the front. Prior studies examining quarter interdependence for IMI and clinical mastitis have reported a higher prevalence in hind quarters compared with front quarters (Adkinson et al., 1993; Barkema et al., 1997). Conversely, the majority of studies evaluating the use of ITS have failed to report a quarter effect (Berry and Hillerton, 2002a; Huxley et al., 2002; Godden et al., 2003).

Another association revealed in the final multivariable model was the effect of season on IMI risk at calving. According to the data, quarters belonging to cows that calved in the summer and fall were more likely to have an IMI postcalving than quarters belonging to cows that calved in the winter. Others have hypothesized that higher temperatures and increased humidity in the summer and early fall result in a greater pathogen load in the environment (Smith et al., 1985; Todhunter et al., 1995), as well as increased cow susceptibility due to immunosuppression from heat stress (Smith et al., 1985; Carroll and Forsberg, 2007). Similarly, different housing and nutrition in the warmer months may explain some of the seasonality effect (Godden et al., 2003).

\section{Limitations of the Study}

According to the initial study design, exclusion rates based on SCC data from the NCDF were expected to be approximately $30 \%$ of cows. It was also estimated that an additional $10 \%$ of cows would be excluded based on other criteria. Ultimately, $37 \%$ of cows were ineligible due to high SCC, and an additional $17 \%$ were excluded for other reasons. As a result of higher-than-anticipated exclusion rates, in addition to postenrollment losses, the final sample size used in the analysis was smaller than what was declared required to maintain a power of 0.80 . The concern with small sample sizes is a lack of power to detect differences where differences exist, especially when the difference is small. Although at no time were there trends in treatment group factor effects approaching significance, it should be noted that maintaining a power of 0.80 using the effective sample size attained in this study, the smallest detectable difference between BDCT and SDCT group would be $6.5 \%$.

\section{CONCLUSIONS}

Following the selection protocol outlined in the current study, which included criteria based on historical SCC with the addition of Petrifilm on-farm culture, a total reduction in DCT of $21 \%$ was realized. The use of a Petrifilm-based on-farm culture system to make targeted DCT treatment decisions on cows with a low SCC at the end of lactation did not affect the risk of IMI at calving or the risk of clinical mastitis in the first 120 DIM, compared with BDCT. Although application of the Petrifilm on-farm culture system at the cow level (i.e., composite milk samples and cow-level treatment) led to a modest decrease in the use of DCT in the study herds, use of the culture system at the quarter level (i.e., quarter samples and quarter-level treatment) has the potential to effect an even greater reduction in the use of intramammary antimicrobials at the end of lactation and is the focus of a forthcoming research project. Analysis of the economics of Petrifilm-based SDCT is currently being conducted.

\section{ACKNOWLEDGMENTS}

This research was financed by Maritime Quality Milk, a research program of the Atlantic Veterinary College, University of Prince Edward Island (Charlottetown, PE, Canada), and Novalait Inc. (Quebec, QC, Canada). Additional funding was provided by the Prince Edward Island Department of Innovation and Advanced Learning (Charlottetown, PE, Canada). The authors thank François Dubois Faculté de médecine vétérinaire, Université de Montréal, Saint-Hyacinthe, QC, Canada) and Theresa Andrews, Natasha Robinson, and Lloyd Dalziel (all from Atlantic Veterinary College, University of Prince Edward Island, Charlottetown, PE, Canada) for their technical assistance, the laboratory personnel from Maritime Quality Milk, and the participating dairy producers.

\section{REFERENCES}

Adkinson, R. W., K. H. Ingawa, D. C. Blouin, and S. C. Nickerson. 1993. Distribution of clinical mastitis among quarters of the bovine udder. J. Dairy Sci. 76:3453-3459.

Barkema, H. W., Y. H. Schukken, T. J. Lam, D. T. Galligan, M. L. Beiboer, and A. Brand. 1997. Estimation of interdependence 
among quarters of the bovine udder with subclinical mastitis and implications for analysis. J. Dairy Sci. 80:1592-1599.

Berry, D. P., and W. J. Meaney. 2006. Interdependence and distribution of subclinical mastitis and intramammary infection among udder quarters in dairy cattle. Prev. Vet. Med. 75:81-91.

Berry, E. A., and J. E. Hillerton. 2002a. The effect of an intramammary teat seal on new intramammary infections. J. Dairy Sci. $85: 2512-2520$.

Berry, E. A., and J. E. Hillerton. 2002b. The effect of selective dry cow treatment on new intramammary infections. J. Dairy Sci. 85:112-121.

Berry, E. A., H. Hogeveen, and J. E. Hillerton. 2004. Decision tree analysis to evaluate dry cow strategies under UK conditions. J. Dairy Res. 71:409-418.

Berry, E. A., W. T. Johnston, and J. E. Hillerton. 2003. Prophylactic effects of two selective dry cow strategies accounting for interdependence of quarter. J. Dairy Sci. 86:3912-3919.

Bhutto, A. L., R. D. Murray, and Z. Woldehiwet. 2012. California mastitis test scores as indicators of subclinical intra-mammary infections at the end of lactation in dairy cows. Res. Vet. Sci. $92: 13-17$.

Bradley, A. 2002. Bovine mastitis: An evolving disease. Vet. J. 164:116-128.

Bradley, A. J., J. E. Breen, B. Payne, and M. J. Green. 2011. A comparison of broad-spectrum and narrow-spectrum dry cow therapy used alone and in combination with a teat sealant. J. Dairy Sci. 94:692-704.

Bradley, A. J., J. E. Breen, B. Payne, P. Williams, and M. J. Green. 2010. The use of a cephalonium containing dry cow therapy and an internal teat sealant, both alone and in combination. J. Dairy Sci. 93:1566-1577.

Bradley, A. J., and M. J. Green. 2000. A study of the incidence and significance of intramammary enterobacterial infections acquired during the dry period. J. Dairy Sci. 83:1957-1965.

Bradley, A. J., and M. J. Green. 2004. The importance of the nonlactating period in the epidemiology of intramammary infection and strategies for prevention. Vet. Clin. North Am. Food Anim. Pract. 20:547-568.

Browning, J. W., G. A. Mein, M. Barton, T. J. Nicholls, and P. Brightling. 1990. Effects of antibiotic therapy at drying off on mastitis in the dry period and early lactation. Aust. Vet. J. 67:440-442.

Browning, J. W., G. A. Mein, P. Brightling, T. J. Nicholls, and M. Barton. 1994. Strategies for mastitis control: Dry cow therapy and culling. Aust. Vet. J. 71:179-181.

Call, D. R., M. A. Davis, and A. A. Sawant. 2008. Antimicrobial resistance in beef and dairy cattle production. Anim. Health Res. Rev. 9:159-167.

Cameron, M., G. P. Keefe, J. P. Roy, I. R. Dohoo, K. A. Macdonald, and S. L. McKenna. 2013. Evaluation of a 3M Petrifilm onfarm culture system for the detection of intramammary infection at the end of lactation. Prev. Vet. Med. 111:1-9. http://dx.doi. org/10.1016/j.prevetmed.2013.03.006.

Carroll, J. A., and N. E. Forsberg. 2007. Influence of stress and nutrition on cattle immunity. Vet. Clin. North Am. Food Anim. Pract. 23:105-149.

Dingwell, R. T., K. E. Leslie, Y. H. Schukken, J. M. Sargeant, L. L. Timms, T. F. Duffield, G. P. Keefe, D. F. Kelton, K. D. Lissemore, and J. Conklin. 2004. Association of cow and quarter-level factors at drying-off with new intramammary infections during the dry period. Prev. Vet. Med. 63:75-89.

Dohoo, I., S. Andersen, R. Dingwell, K. Hand, D. Kelton, K. Leslie, Y. Schukken, and S. Godden. 2011a. Diagnosing intramammary infections: Comparison of multiple versus single quarter milk samples for the identification of intramammary infections in lactating dairy cows. J. Dairy Sci. 94:5515-5522.

Dohoo, I. R., S. W. Martin, and H. Stryhn. 2009. Veterinary Epidemiologic Research. 2nd ed. VER Inc., Charlottetown, PE, Canada.

Dohoo, I. R., J. Smith, S. Andersen, D. F. Kelton, and S. Godden., and Mastitis Research Workers' Conference. 2011b. Diagnosing intramammary infections: Evaluation of definitions based on a single milk sample. J. Dairy Sci. 94:250-261.
Dufour, S., I. R. Dohoo, H. W. Barkema, L. DesCôteaux, T. J. DeVries, K. K. Reyher, J.-P. Roy, and D. T. Scholl. 2012. Manageable risk factors associated with the lactational incidence, elimination, and prevalence of Staphylococcus aureus intramammary infections in dairy cows. J. Dairy Sci. 95:1283-1300.

Godden, S., P. Rapnicki, S. Stewart, J. Fetrow, A. Johnson, R. Bey, and R. Farnsworth. 2003. Effectiveness of an internal teat seal in the prevention of new intramammary infections during the dry and early-lactation periods in dairy cows when used with a dry cow intramammary antibiotic. J. Dairy Sci. 86:3899-3911.

Green, M. J., A. J. Bradley, G. F. Medley, and W. J. Browne. 2007. Cow, farm, and management factors during the dry period that determine the rate of clinical mastitis after calving. J. Dairy Sci. 90:3764-3776

Green, M. J., L. E. Green, A. J. Bradley, P. R. Burton, Y. H. Schukken, and G. F. Medley. 2005. Prevalence and associations between bacterial isolates from dry mammary glands of dairy cows. Vet. Rec. 156:71-77.

Green, M. J., L. E. Green, G. F. Medley, Y. H. Schukken, and A. J. Bradley. 2002. Influence of dry period bacterial intramammary infection on clinical mastitis in dairy cows. J. Dairy Sci. 85:2589 2599.

Gruet, P., P. Maincent, X. Berthelot, and V. Kaltsatos. 2001. Bovine mastitis and intramammary drug delivery: Review and perspectives. Adv. Drug Deliv. Rev. 50:245-259.

Halasa, T., M. Nielen, A. C. Whist, and O. Østerås. 2009a. Metaanalysis of dry cow management for dairy cattle. Part 2. Cure of existing intramammary infections. J. Dairy Sci. 92:3150-3157.

Halasa, T., O. Østerås, H. Hogeveen, T. van Werven, and M. Nielen. 2009b. Meta-analysis of dry cow management for dairy cattle. Part 1. Protection against new intramammary infections. J. Dairy Sci. 92:3134-3149

Harmon, R. J., W. L. Crist, R. W. Hemken, and B. E. Langlois. 1986. Prevalence of minor udder pathogens after intramammary dry treatment. J. Dairy Sci. 69:843-849.

Hassan, Z., R. C. Daniel, D. O'Boyle, and A. J. Frost. 1999. Effects of dry cow intramammary therapy on quarter infections in the dry period. Vet. Rec. 145:635-639.

Hillerton, J. E., A. J. Bramley, R. T. Staker, and C. H. McKinnon. 1995. Patterns of intramammary infection and clinical mastitis over a 5 year period in a closely monitored herd applying mastitis control measures. J. Dairy Res. 62:39-50.

Hogan, J. S., K. L. Smith, D. A. Todhunter, and P. S. Schoenberger. 1988. Rate of environmental mastitis in quarters infected with Corynebacterium bovis and Staphylococcus species. J. Dairy Sci. $71: 2520-2525$

Huijps, K., and H. Hogeveen. 2007. Stochastic modeling to determine the economic effects of blanket, selective, and no dry cow therapy. J. Dairy Sci. 90:1225-1234.

Huxley, J. N., M. J. Green, L. E. Green, and A. J. Bradley. 2002. Evaluation of the efficacy of an internal teat sealer during the dry period. J. Dairy Sci. 85:551-561.

McCarron, J. L., G. P. Keefe, S. L. McKenna, I. R. Dohoo, and D. E. Poole. 2009. Laboratory evaluation of 3M Petrifilms and University of Minnesota Bi-plates as potential on-farm tests for clinical mastitis. J. Dairy Sci. 92:2297-2305.

Newton, H. T., M. J. Green, H. Benchaoui, V. Cracknell, T. Rowan, and A. J. Bradley. 2008. Comparison of the efficacy of cloxacillin alone and cloxacillin combined with an internal teat sealant for dry-cow therapy. Vet. Rec. 162:678-684.

NMC (National Mastitis Council). 1999. Laboratory Handbook on Bovine Mastitis. Rev. ed. National Mastitis Council Inc., Madison, WI.

NMC (National Mastitis Council). 2006. Recommended mastitis control plan. Accessed May 8, 2013. http://www.nmconline.org/docs/ NMCchecklistInt.pdf.

Olde Riekerink, R. G., H. W. Barkema, D. T. Scholl, D. E. Poole, and D. F. Kelton. 2010. Management practices associated with the bulk-milk prevalence of Staphylococcus aureus in Canadian dairy farms. Prev. Vet. Med. 97:20-28. 
Olde Riekerink, R. G., H. W. Barkema, S. Veenstra, D. E. Poole, R. T. Dingwell, and G. P. Keefe. 2006. Prevalence of contagious mastitis pathogens in bulk tank milk in Prince Edward Island. Can. Vet. J. $47: 567-572$.

Oliver, S. P., T. M. Lewis, M. J. Lewis, H. H. Dowlen, and J. L. Maki. 1990. Persistence of antibiotics in bovine mammary secretions following intramammary infusion at cessation of milking. Prev. Vet. Med. 9:301-311.

Oliver, S. P., S. E. Murinda, and B. M. Jayarao. 2011. Impact of antibiotic use in adult dairy cows on antimicrobial resistance of veterinary and human pathogens: A comprehensive review. Foodborne Pathog. Dis. 8:337-355.

Østerås, O., and L. Sandvik. 1996. Effects of selective dry-cow therapy on culling rate, clinical mastitis, milk yield and cow somatic cell count. A randomized clinical field study in cows. Zentralbl. Veterinärmed. B. $43: 555-575$.

Pyörälä, S., and S. Taponen. 2009. Coagulase-negative staphylococciEmerging mastitis pathogens. Vet. Microbiol. 134:3-8.

Rainard, P., and B. Poutrel. 1988. Effect of naturally occurring intramammary infections by minor pathogens on new infections by major pathogens in cattle. Am. J. Vet. Res. 49:327-329.

Rajala-Schultz, P. J., A. H. Torres, and F. J. Degraves. 2011. Milk yield and somatic cell count during the following lactation after selective treatment of cows at dry-off. J. Dairy Res. 78:489-499.

Rajala-Schultz, P. J., A. H. Torres, F. J. DeGraves, W. A. Gebreyes, and P. Patchanee. 2009. Antimicrobial resistance and genotypic characterization of coagulase-negative staphylococci over the dry period. Vet. Microbiol. 134:55-64.

Reyher, K. K., S. Dufour, H. W. Barkema, L. Des Côteaux, T. J. DeVries, I. R. Dohoo, G. P. Keefe, J.-P. Roy, and D. T. Scholl. 2011. The National Cohort of Dairy Farms - A data collection platform for mastitis research in Canada. J. Dairy Sci. 94:16161626.

Reyher, K. K., D. Haine, I. R. Dohoo, and C. W. Revie. 2012. Examining the effect of intramammary infections with minor mastitis pathogens on the acquisition of new intramammary infections with major mastitis pathogens-A systematic review and meta-analysis. J. Dairy Sci. 95:6483-6502.

Rindsig, R. B., R. G. Rodewald, A. R. Smith, and S. L. Spahr. 1978. Complete versus selective dry cow therapy for mastitis control. J. Dairy Sci. 61:1483-1497.

Robert, A., N. Bareille, P. Roussel, B. Poutrel, V. Heuchel, and H. Seegers. 2006a. Interdependence of udder quarters for new intramammary infection during the dry period in cows submitted to selective antibiotic therapy. J. Dairy Res. 73:345-352.

Robert, A., P. Roussel, N. Bareille, D. Ribaud, F. Sérieys, V. Heuchel, and H. Seegers. 2008. Risk factors for new intramammary infections during the dry period in untreated dairy cows from herds using selective dry cow therapy. Animal 2:247-254.

Robert, A., H. Seegers, and N. Bareille. 2006b. Incidence of intramammary infections during the dry period without or with antibiotic treatment in dairy cows-A quantitative analysis of published data. Vet. Res. 37:25-48.

Robinson, T. C., E. R. Jackson, and A. Marr. 1988. Mastitis incidence in quarters with different infection status at drying off and calving in two treatment groups. Br. Vet. J. 144:166-173.

Roy, J.-P., and G. Keefe. 2012. Systematic review: What is the best antibiotic treatment for Staphylococcus aureus intramammary infection of lactating cows in North America? Vet. Clin. North Am. Food Anim. Pract. 28:39-50.

Ruegg, P. L. 2012. New perspectives in udder health management. Vet. Clin. North Am. Food Anim. Pract. 28:149-163.

Saini, V., J. T. McClure, D. Leger, S. Dufour, A. G. Sheldon, D. T. Scholl, and H. W. Barkema. 2012. Antimicrobial use on Canadian dairy farms. J. Dairy Sci. 95:1209-1221.

Sanford, C. J., G. P. Keefe, I. R. Dohoo, K. E. Leslie, R. T. Dingwell, L. DesCôteaux, and H. W. Barkema. 2006a. Efficacy of using an internal teat sealer to prevent new intramammary infections in nonlactating dairy cattle. J. Am. Vet. Med. Assoc. 228:15651573.

Sanford, C. J., G. P. Keefe, J. Sanchez, R. T. Dingwell, H. W. Barkema, K. E. Leslie, and I. R. Dohoo. 2006b. Test characteristics from latent-class models of the California Mastitis Test. Prev. Vet. Med. 77:96-108.

Schukken, Y. H., R. N. González, L. L. Tikofsky, H. F. Schulte, C. G. Santisteban, F. L. Welcome, G. J. Bennett, M. J. Zurakowski, and R. N. Zadoks. 2009. CNS mastitis: Nothing to worry about? Vet. Microbiol. 134:9-14.

Smith, K. L., D. A. Todhunter, and P. S. Schoenberger. 1985. Environmental mastitis: Cause, prevalence, prevention. J. Dairy Sci. 68:1531-1553.

Todhunter, D. A., K. L. Smith, and J. S. Hogan. 1995. Environmental streptococcal intramammary infections of the bovine mammary gland. J. Dairy Sci. 78:2366-2374.

Torres, A. H., P. J. Rajala-Schultz, F. J. Degraves, and K. H. Hoblet. 2008. Using dairy herd improvement records and clinical mastitis history to identify subclinical mastitis infections at dry-off. J. Dairy Res. 75:240-247.

USDA (US Department of Agriculture). 2008. Dairy 2007. Part III Reference of Dairy Cattle Health and Management Practices in the United States, 2007. \#N482.0908. USDA-Animal and Plant Health Inspection Service-Veterinary Services, Centers for Epidemiology and Animal Health (USDA-APHIS-VS, CEAH), National Animal Health Monitoring System, Fort Collins, CO.

Williamson, J. H., M. W. Woolford, and A. M. Day. 1995. The prophylactic effect of a dry-cow antibiotic against Streptococcus uberis. N. Z. Vet. J. 43:228-234.

Woolford, M. W., J. H. Williamson, A. M. Day, and P. J. Copeman. 1998. The prophylactic effect of a teat sealer on bovine mastitis during the dry period and the following lactation. N. Z. Vet. J. 46:12-19. 